\title{
CRYSTAL-CELL INTERACTION INHIBITION BY POLYSACCHARIDES
}

\author{
C. F. VERKOELEN,* J. C. ROMIJN, L. C. CAO, E. R. BOEVE, W. C. DE BRUIJN AND \\ F. H. SCHRÖDER \\ From the Department of Urology and the Institute of Clinical Pathology, AEM-Unit, Erasmus University and Academic Hospital \\ Rotterdam, Rotterdam, The Netherlands
}

\begin{abstract}
Purpose: We studied the effect of polysaccharides on interactions between calcium oxalate monohydrate (COM) crystals and cultured renal cells.

Materials and Methods: Monolayers of Madin-Darby canine kidney (MDCK) cells were incubated with radiolabeled crystals in the presence of various concentrations of natural glycosaminoglycans (GAGs) and semisynthetic polysaccharides (SSPs).

Results: While most GAGs were found to have relatively little effect, SSPs (SP54, G871 and G872) were potent inhibitors of crystal-cell association. Pretreatment of crystals, but not of cells, was similarly effective, suggesting polysaccharide-induced modification of crystal surface properties.

Conclusions: This result further supports the idea that SSPs, and especially G872, are of potential interest for treatment of recurrent stone disease.
\end{abstract}

KEY WORDS: calcium oxalate, glycosaminoglycans, polysaccharides

Urinary supersaturation, crystal growth and agglomeration and crystal retention are considered important factors in the pathogenesis of calcium oxalate nephrolithiasis. ${ }^{1-3}$ Crystal retention could be caused by physical entrapment as a result of increased particle size, disturbed urinary flow, or adhesion to the brush border of renal tubular cells. ${ }^{4}$ Several investigators have reported on the attachment and subsequent interaction of calcium oxalate crystals with renal tubular cells in culture. ${ }^{5.6}$ The possible role of glycosaminoglycans (GAGs) in crystal-cell interaction has not yet been fully investigated. Urinary GAGs are found to be potent inhibitors of crystallization. ${ }^{1-3}$ Metabolic disorders resulting in a modification of the characteristics of urinary GAGs could play a role in renal stone disease. Several GAGs are known to occur in urine; these include hyaluronic acid (HA), chondroitin-4sulfate (CS-A), dermatan sulfate (CS-B), chondroitin-6-sulfate (CS-C), heparan sulfate (HS) and keratan sulfate (KS) ${ }^{1,2}$ In addition, GAGs are also present at the apical surface of renal tubule cells where they are linked as polysaccharide side-chains to the core proteins of plasma membrane associated proteoglycans. ${ }^{7}$ It has been suggested that these cell surface constituents in uroepithelial cells provide a protective layer that prevents retention of crystals. ${ }^{8,9}$ Considering the relatively high turnover of the cell surface coat, shedded GAGs may constitute a major fraction of the urinary GAG pool. Since the inhibitory activity of crystallization in the urine of recurrent stone formers is often decreased, ${ }^{3}$ it has been suggested that oral administration of synthetic polysaccharides could contribute to the prevention of stone formation by increasing the overall urinary inhibitory activity. $1,2,10,11$ In cooperation with the Ocean University of Qindao, China, our institute investigates the potential use of a group of synthetic polysaccharides (SSPs) derived from marine algae. 1, 10,11,12 These substances have been shown to be powerful inhibitors of crystal growth and agglomeration. This paper describes the effect of various polysaccharides on calcium oxalate monohydrate (COM) crystal-cell interaction.

Accepted for publication August 4, 1995.

* Requests for reprints: Department of Urology/Ee 1006, Erasmus University Rotterdam, P.O. Box 1738, 3000 DR Rotterdam, The Netherlands.

This study was supported by the Dutch Kidney Foundation through Grant C 92.1235.

\section{MATERIALS AND METHODS}

Cell culture. Madin-Darby canine kidney (MDCK cells), strain II, were obtained from the American Type Culture Collection (ATCC, Rockville, Maryland) and used between passage numbers 30 and 50. The cells were cultured in Dulbecco's modified MEM supplemented with $10 \%$ fetal calf serum, $20 \mathrm{mM}$. HEPES, $2 \mathrm{mM}$. L-glutamine, $100 \mathrm{IU} / \mathrm{ml}$. penicillin and $100 \mu \mathrm{g} . \mathrm{ml}$. streptomycin. The medium was refreshed every 2 days. The cells were routinely grown in plastic tissue culture flasks (Costar, Badhoevedorp, The Netherlands) at $37 \mathrm{C}$ in a humidified atmosphere of $5 \% \mathrm{CO}_{2}$ in air. Subculturing was performed weekly with $0.05 \%$ trypsin $10.02 \%$ EDTA (GIBCO-BRL, United Kingdom). When cultured in a 2-compartment culture system on $24-\mathrm{mm}$. porous cell culture inserts with a $0.4 \mu \mathrm{m}$. pore size (Costar), MDCK cells form polarized monolayers. Cells were seeded at a density of $1 \times 10^{6}$ cells per insert. Although closed monolayers were formed within 2 days, the cells were cultured for an additional period of time to allow full expression of differentiated characteristics. Crystal-cell interaction studies were performed 8 days after the cells were seeded. ${ }^{13}$

Preparation of calcium oxalate crystal suspensions. A solution of radioactive oxalic acid was prepared by adding $1 \mathrm{ml}$. $0.01 \mathrm{mCi} . / \mathrm{ml}$. $\left(0.37 \mathrm{MBq} / \mathrm{ml}\right.$.) $\left[{ }^{14} \mathrm{C}\right.$ ]oxalic acid $(4.03 \mathrm{GBq}$ ' mmol., Amersham International, Little Chalfont, Buckinghamshire, United Kingdom) to $0.5 \mathrm{ml}$. $200 \mathrm{mM}$. sodium oxalate. A calcium chloride solution was prepared by adding 0.5 $\mathrm{ml}$. $200 \mathrm{mM}$. calcium chloride to $8 \mathrm{ml}$. distilled water. The two solutions were mixed at room temperature, resulting in a final concentration of $10 \mathrm{mM}$. for both calcium and oxalate, and $\left[{ }^{14} \mathrm{C}\right]$-labeled $\mathrm{CaOx}$ crystals with an average size of 2.03 $\mu \mathrm{m} .{ }^{13}$ were formed immediately. The crystal suspension was allowed to equilibrate for 3 days. The crystals were then washed 3 times with (sodium and chloride-free) $\mathrm{CaOx}$ saturated distilled water, resuspended and stored in $5 \mathrm{ml}$. of this solution. The radioactive crystal suspension contained 2.92 mg. $\mathrm{CaOx}$ crystals per $\mathrm{ml}$. X-ray diffraction of the crystals was studied with an X-ray generator PW 1729/00 connected to an Integrator/Interface PW 1842 (Philips, Eindhoven, The Netherlands), and demonstrated that they consisted exclusively of calcium oxalate monohydrate (COM).

Crystal-cell interaction studies. Crystal-cell interaction 
was studied in a $\mathrm{CaOx}$ saturated buffer (buffer $\mathrm{B}$ ) that was prepared by the addition of an excess COM crystals ( $3 \mathrm{mg} . /$ ml.) to a buffer ( $\mathrm{pH} \mathrm{6.7)} \mathrm{containing} \mathrm{(in} \mathrm{mM}$.): $118 \mathrm{NaCl}, 5.3$ $\mathrm{KCl}, 1.8 \mathrm{CaCl}_{2}, 6.6 \mathrm{NaHCO}_{3}, 1.3 \mathrm{MgSO}_{4}, 2.0 \mathrm{NaH}_{2} \mathrm{PO}_{4}$ and 20 HEPES. The cells were washed and preincubated with HEPES buffered serum-free DMEM and added to the apical compartment facing the luminal plasma membrane and the basal compartment facing the contraluminal plasma membrane. After 1 hour, $1.5 \mathrm{ml}$. buffer $B$ was added to the apical compartment and $2.6 \mathrm{ml}$. fresh serum-free DMEM to the basal compartment. Polysaccharides were added at the apical side of the monolayers. Subsequently, $50 \mu$ l. of the crystal suspension (146 $\mu \mathrm{g}$.), prepared as described above, was distributed homogeneously on top of the cells. After an incubation period of 60 minutes, the monolayers were rinsed in 3 successive buffer $B$ baths to remove nonassociated crystals. The filter inserts were cut out with a scalpel and transferred to a scintillation vial. To extract radioactivity, $1 \mathrm{ml} .1 \mathrm{M}$. perchloric acid was added and the amount of radioactivity was counted in a liquid scintillation counter (Packard, Meriden, Connecticut). The results were calculated as dpm per filter and expressed as percentage crystal-cell association compared with untreated controls. The inhibitory activity of the various polysaccharides was expressed as IC-50 value, which represents the concentration that results in a $50 \%$ inhibition compared with untreated controls.

To investigate whether polysaccharides interacted with the cells, the monolayers were incubated with the compound of interest in a volume of $1.5 \mathrm{ml}$. for periods of 5 minutes to 48 hours. After this treatment the monolayers were rinsed 3 times with PBS, and crystal-cell interaction was studied as described. To investigate whether polysaccharides interacted with the crystal surface, the compound of interest was added to the crystal suspension $(146 \mu \mathrm{g}$. crystals in $1.5 \mathrm{ml}$. buffer B). After 5 minutes the suspension was centrifuged, the supernatant removed and the crystals washed 3 times with fresh buffer $B$. Washed crystals were resuspended in fresh polysaccharide-free buffer $B$ and crystal-cell interaction studies performed as described.

Polysaccharides. G871 and G872,"1 semisynthetic sulfated polyguluronic propionates, extracted from marine algae and prepared through physicochemical modification, were kindly provided by Professor Guan Hua-Shi, director of the Institute of Food and Drugs, Ocean University of Qingdao, China. Pentosan polysulfate (SP54), a semisynthetic oligosaccharide obtained after the sulfation of a naturally occurring xylan composed of repeating $\beta$-D- 1->4-xylopyranose residues, was provided by Bene Artzneimittel GmbH (München, Germany). Glycosaminoglycans are naturally occurring highly negatively charged linear polysaccharides. They consist of repeating disaccharide units of alternating hexosamine and hexuronic acid residues. Heparin (porcine intestinal mucosa), heparan sulfate (bovine kidney), chondroitin sulfate-A (bovine trachea), CS-B (bovine mucosa), CS-C (shark cartilage) and hyaluronic acid (human umbilical cord) were obtained from Sigma Chemical Co. (St. Louis, Missouri).

Statistics. All experiments were performed at least 2 times. The results are presented as means \pm SD of 3 independent filters. Statistical analysis was performed with a one-way analysis of variance (ANOVA) or Student's t test. Differences were considered significant at $p<0.05$.

\section{RESULTS}

Crystal-cell interaction studies were performed in the presence of various polysaccharides. In the group of naturally occurring GAGs, $\mathrm{HA}$ and CS-C in concentrations as great as $100 \mu \mathrm{g} . / \mathrm{ml}$. did not exhibit an inhibitory effect that is significantly different from untreated controls. A concentrationdependent statistically significant inhibitory effect was observed with H, HS, CS-A and CS-B (ANOVA, p $<0.05$ ).
Heparin, the most effective natural polysaccharide, inhibits COM-crystal interaction with MDCK cells for about $90 \%$ at a concentration of $25 \mu \mathrm{g} . / \mathrm{ml}$. (fig. 1). The SSPs tested exhibited strong inhibitory activity at much lower concentrations. All 3 semisynthetic compounds had a statistically significant inhibitory effect (ANOVA, $p<0.05$ ) on the association of COMcrystals in a range of 0.01 to $2.0 \mu \mathrm{g} . / \mathrm{ml}$. (fig. 2). The IC-50 values derived from the curves shown in figures 1 and 2 , are listed in table 1 . The most potent inhibitor was G872. The inhibitory effect of G872 on crystal-cell interaction at concentrations of 0.5 and $2 \mu \mathrm{g} . / \mathrm{ml}$. was significantly stronger than that of G871 and SP54 at these concentrations (fig. 2).

To investigate whether the inhibitory effects of polysaccharides on crystal-cell interaction are caused by alterations of the cell surface, of the crystal surface, or both, cells and crystals were individually treated prior to the determination of their interaction. Based on the data shown in figures 1 and 2 , concentrations of G872 (2 $\mu \mathrm{g} . / \mathrm{ml}$.) and heparin $(25 \mu \mathrm{g} . / \mathrm{ml}$.) were selected with comparable inhibitory effects on crystalcell interaction ( $10 \pm 2$ and $18 \pm 3 \%$ of control, see table 2 ). Pretreatment of the cells for 5 minutes or 1,24 , or 48 hours by either compound did not cause significant inhibition of interaction with crystals (table 2 ). The same result was obtained with CS-B, HS, or SP54 (data not shown). In contrast, preincubation of the crystal suspension (followed by extensive washing as described in Materials and Methods and without subsequent addition of polysaccharides) resulted in an inhibitory effect that was of the same order of magnitude as the inhibition obtained in the continuous presence of these compounds ( $23 \pm 3$ and $15 \pm 3 \%$ of control, see table 2 ).

\section{DISCUSSION}

The association of $\mathrm{CaOx}$ crystals with renal tubular cells could be an early event in the pathogenesis of nephrolithiasis. After induction of hyperoxaluria and subsequent crystalluria it has been found that crystals are retained in the renal tubules of rats. ${ }^{14,15}$ Scanning electron microscopic images demonstrated that $\mathrm{CaOx}$ crystals were tightly attached to the luminal surface of renal tubular cells in a patient with hyperoxaluria. ${ }^{16}$ In patients with primary hyperoxaluria who received a kidney transplant, postoperative biopsies revealed the presence of $\mathrm{CaOx}$ crystals within renal tubular cells. ${ }^{17}$ We have previously characterized a model system in which the association of $\mathrm{CaOx}$ crystals with MDCK monolayers was investigated by using radioactively labeled COM-crystals. ${ }^{13}$

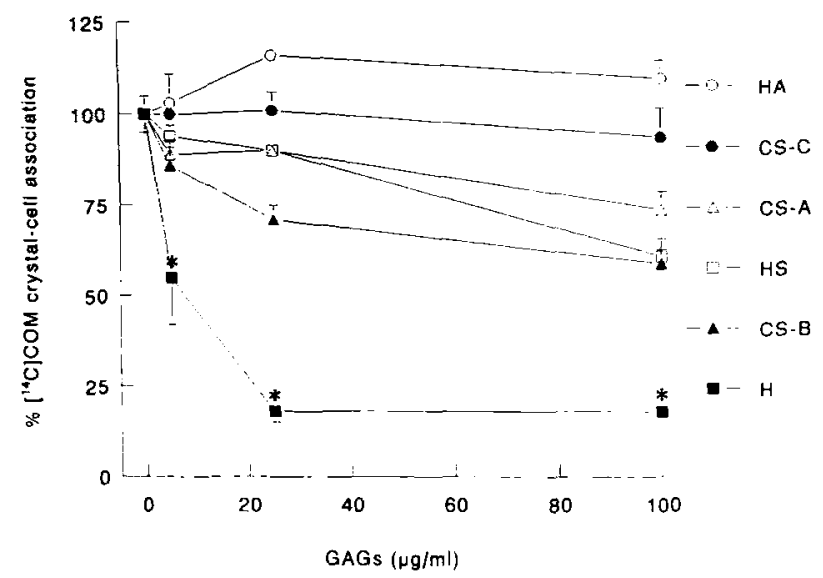

Fig. 1. Effect of glycosaminoglycans on interaction of COM crystals with MDCK cells (HA: hyaluronic acid; CS-A,B,C: chondroitin sulfate-A,B,C; HS: heparan sulfate; H: heparin). Statistically significant trend is observed with H, HS, CS-A and CS-B (ANOVA, $\mathrm{p}<0.05, \mathrm{n}=3$ ). * Significant difference between $\mathrm{H}$ and other GAGs (Student's t test, $\mathrm{p}<0.001, \mathrm{n}=3$ ). 


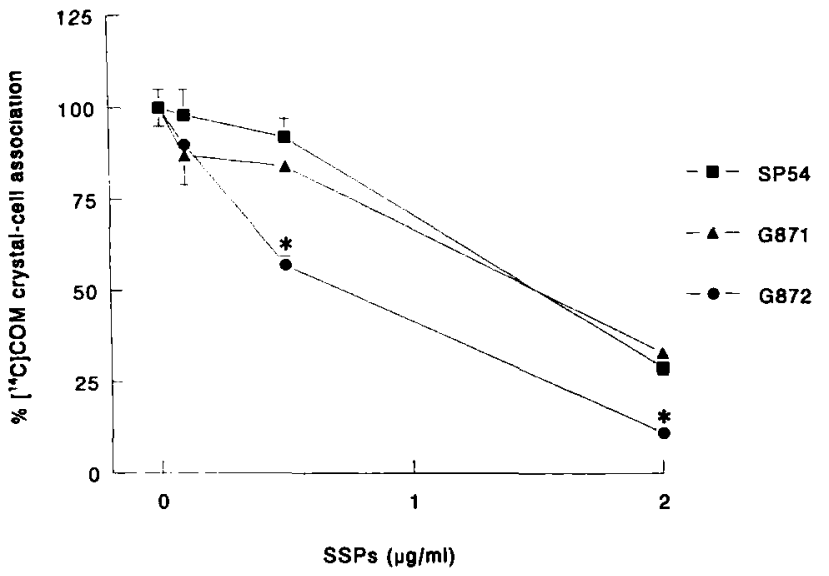

Fig. 2. Effect of semisynthetic polysaccharides (SP54, G871 and G872) on interaction of COM crystals with MDCK cells. Statistically significant trend with $\mathrm{H}, \mathrm{HS}$, CS-A and CS-B (ANOVA, $p<0.05$, $\mathrm{n}=3$ ). * Significant difference between G872 and other SSPs (Student's $t$ test, $\mathrm{p}<0.001, \mathrm{n}=3$ ).

TABLE 1. IC-50 ( $\mu \mathrm{g} . / \mathrm{ml}$.) of polysaccharides in COM crystal-cell interaction inhibition

\begin{tabular}{|c|c|}
\hline \multicolumn{2}{|c|}{ GAGs } \\
\hline $\begin{array}{l}\text { hyaluronic acid } \\
\text { heparan sulfate } \\
\text { chondroitin sulfate-A } \\
\text { chondroitin sulfate-B } \\
\text { chondroitin sulfate-C } \\
\text { heparin }\end{array}$ & $\begin{array}{r}>100 \\
>100 \\
>100 \\
>100 \\
>100 \\
\quad 3.1 \\
\end{array}$ \\
\hline \multicolumn{2}{|c|}{ SSPs } \\
\hline $\begin{array}{l}\text { SP54 } \\
\text { G871 } \\
\text { G872 }\end{array}$ & $\begin{array}{l}2.0 \\
1.8 \\
0.6\end{array}$ \\
\hline
\end{tabular}

TABLE 2. Effect of continuous exposure with and preincubation to polysaccharides on crystal-cell interaction. Data expressed relative to the amount of crystals associated with untreated controls $(100 \%)$

\begin{tabular}{lccc}
\hline & $\begin{array}{c}\text { Continuous } \\
\text { Exposure } \\
(\%)\end{array}$ & $\begin{array}{c}\text { Pretreated } \\
\text { Cells } \\
(\%)\end{array}$ & $\begin{array}{c}\text { Pretreated } \\
\text { Crystals } \\
(\%)\end{array}$ \\
\hline Heparin $25 \mu \mathrm{g} . / \mathrm{ml}$. & $10 \pm 2$ & $106 \pm 3$ & $23 \pm 3$ \\
G872 $2 \mu \mathrm{g} . / \mathrm{ml}$. & $18 \pm 3$ & $95 \pm 2$ & $15 \pm 3$ \\
\hline
\end{tabular}

Monolayer-associated radioactivity represents crystals attached to the cell surface as well as endocytosed crystals. ${ }^{13}$ The present study was initiated to reveal the possible inhibitory effect of naturally occurring and synthetic polysaccharides on crystal-cell association. Having confirmed such an inhibitory activity, it was shown that interaction of polysaccharides with the crystal surface, rather than with the cell surface accounted for the observed effect.

It was demonstrated in a previous study ${ }^{11}$ using a constant composition crystallization model and a seeded crystal growth system that G871, G872 and SP54 (10 $\mu \mathrm{g} . / \mathrm{ml}$.) exhibited strong inhibitory effects on COM-crystal growth and agglomeration in artificial urine and were capable of shifting the COM particle zeta potential in the negative direction. G872 had a significantly greater effect than either G871 or SP54 on all the measured parameters. " The present study showed that SSPs are also potent inhibitors of crystal-cell interaction, with IC-50 values ranging from 0.6 to $2.0 \mu \mathrm{g} . / \mathrm{ml}$. (table 1). Again G872 was the most effective compound. Naturally occurring GAGs had only limited efficacy in this system (fig. 1). Only relatively high concentrations of HS, CS-A and CS-B $(100 \mu \mathrm{g} . / \mathrm{ml}$.) resulted in some protection of the cells against the interaction with COM-crystals. The only naturally occurring polysaccharide that exhibits a considerable inhibitory activity was heparin. However, heparin is normally not present in human urine. Although other natural GAGs are excreted in the urine (average amount $\pm 25 \mathrm{mg}$. per day $)^{18}$ and contribute to the overall urinary inhibitory activity, ${ }^{1-3}$ the results from this study indicate that, in this concentration, these substances do not seem to play an important role in the prevention of crystal retention. Nevertheless, it cannot be excluded that natural GAGs may confer anticrystal adherence properties on the cell surface. Being the polysaccharide side-chains of membrane-associated proteoglycans, GAGs constitute a negatively charged hydrophyllic layer that binds water molecules and thereby protects the cell membrane against direct contact with circulating material. Free GAGs from the incubation medium, however, will not be readily incorporated into such a structure because the assembly of proteoglycans is a complex intracellular process. Inhibition of crystal-cell interactions by polysaccharides was also reported from studies with rat bladder.8,9 Glycosaminoglycans at the surface of rat bladder epithelium were found to act as natural barriers against the adherence of crystals. Damage of the mucous layer resulted in increased $\mathrm{CaOx}$ crystal retention, which could be reduced by the administration of heparin or SP54. ${ }^{8}$ Gill et al..$^{9}$ demonstrated that, in contrast to heparin, $\mathrm{CS}-\mathrm{C}$ and $\mathrm{HA}$ could not prevent $\mathrm{CaOx}$ crystal adhesion to the chemically injured rat bladder. The presence of cell surface GAGs, located chiefly at the apical plasma membrane, was also demonstrated in kidney cells, ${ }^{7}$ including MDCK cells. ${ }^{19}$

The fact that SSPs are effective in inhibiting crystal growth and agglomeration as well as crystal-cell interaction suggests that treatment of recurrent stone formers with these compounds could contribute to the prevention of stone formation. However, in preliminary clinical studies, SP54 proved ineffective as a treatment for recurrent stone formers, largely because of its limited urinary excretion after oral administration. ${ }^{20}$ Preliminary studies in our institute have suggested that G872 may prove more useful than SP54 since its urinary excretion seems to be higher after oral administration (unpublished observation).

In conclusion, G871 and G872 are potent inhibitors of the interaction of COM crystals with MDCK cells, and their inhibitory activity seems to be mediated by their ability to alter crystal properties. Although it cannot be excluded that the observed effects of polysaccharides in this study are specific for our model system, they could also reflect a general mechanism of action. To test this hypothesis, animal experiments are underway in our laboratory to further investigate the possible value of these compounds in the treatment of recurrent renal $\mathrm{CaOx}$ stone disease.

\section{REFERENCES}

1. Boevé, E. R., Cao, L. C., Verkoelen, C. F., Romijn, J. C., de Bruijn, W. C. and Schröder, F. H.: Glycosaminoglycans and other sulphated polysaccharides in calculogenesis of urinary stones. World J. Urol., 12: 43, 1994.

2. Sallis, J. D.: Glycosaminoglycans as inhibitors of stone formation. Miner. Electrolyte Metab., 13: 273, 1987.

3. Menon, M. and Koul, H.: Calcium oxalate nephrolithiasis. J. Clin. Endocrin. Metab., 74: 703, 1992.

4. Kok, D. J. and Khan, S. R.: Calcium oxalate nephrolithiasis, a free or fixed particle disease. Kidney Int., 46: 847, 1994.

5. Riese, R. J., Mandel, N. S., Wiessner, J. H., Mandel, G. S. Becker, C. G. and Kleinman, J. G.: Cell polarity and calcium oxalate crystal adherence to cultured collecting duct cells. Am. J. Physiol., 262: F177, 1992.

6. Lieske, J. C. and Toback, F. G.: Regulation of renal epithelial cell endocytosis of calcium oxalate monohydrate crystals. Am. J. Physiol., 264: F800, 1993.

7. Spicer, S. S., Baron, D. A., Sato, A. and Schulte, B. A.: Variability of cell surface glycoconjugates. J. Histochem. Cytochem., 29: 
$994,1981$.

8. Parsons, C. L., Stauffer, C. and Schmidt, J. D.: Bladder-surface glycosaminoglycans: an efficient mechanism of environmental adaptation. Science, 208: 605, 1980.

9. Gill, W. B., Jones, K. W. and Ruggiero, K. J.: Protective effects of heparin and other sulfated glycosaminoglycans on crystal adhesion to injured urothelium. J. Urol., 127: 152, 1981.

10. Cao, L. C., Boevé, E. R. and Schröder, F. H.: The mechanisms of action of glycosaminoglycans (GAGs) in calcium oxalate stone prevention: a review. J. Lithotr. Stone Dis., 3: 324, 1991.

11. Cao, L. C., Boevé, E. R., Schröder, F. H., Robertson, W. G., Ketelaars, G. A. M. and de Bruijn, W. C.: The effect of two new semi-synthetic glycosaminoglycans (G871, G872) on the zeta potential of calcium oxalate crystals and on growth and agglomeration. J. Urol., 147: 1643, 1992.

12. Boevé, E. R., Cao, L. C., Schröder, F. H., Ketelaars, G. A. M., Vermey, $M$. and de Bruijn, W. C.: The influence of 3 exogenous glycosaminoglycans on the experimental induction of microliths in rats. Urol. Res., 18: 62, 1990.

13. Verkoelen, C. F., Romijn, J. C., de Bruijn, W. C., Boevé, E. R., Cao, L. C. and Schröder, F. H.: Association of calcium oxalate monohydrate crystals with MDCK cells. Kidney Int., 48: 129, 1995.

14. Khan, S. R. and Hackett, R. L.: Retention of calcium oxalate crystals in renal tubules. Scann. Microsc., 5: 707, 1991.

15. de Bruijn, W. C., Boevé, E. R., van Run, P. R. W. A., van Miert, P. P. M. C., Romijn, J. C., Verkoelen, C. F., Cao, L. C. and Schröder, F. H.: Etiology of experimental calcium oxalate monohydrate nephrolithiasis in rats. Scanning Microsc., 8: 541, 1994.

16. Morgenroth, K., Backmann, R. and Blaschke, R.: On the formation of deposits of calcium oxalate in the human kidney in oxalosis. Beitr. Path. Anat., 136: 454, 1968.

17. Lieske, C. L., Spargo, B. H. and Toback, F. G.: Endocytosis of calcium oxalate crystals and proliferation of renal tubular epithelial cells in a patient with type 1 primary hyperoxaluria. J. Urol., 148: 1517, 1992.

18. Hwang, T. I. S., Preminger, G. M., Poindexter, J. and Pak, C. Y. C.: Urinary glycosaminoglycans in normal subjects and patients with stones. J. Urol., 139: 995, 1988.

19. Takeuchi, J., Mitsuko, S., Mikihiro, S., Masahiko, Y., Emiko, S. and Leighton, J.: Cell surface glycosaminoglycans of cell line MDCK derived from canine kidney. Cancer Res., 37: 1507, 1977.

20. Hesse, A., Wuzel, H. and Vahlensieck, W.: Significance of glycosaminoglycans for the formation of calcium oxalate stones. Am. J. Kidney Dis., 17: 414, 1991. 